\title{
ЛІТЕРАТУРОЗНАВСТВО
}

\section{НАРАТИВНІ СТРАТЕГІЇ В РОМАНІ ІЛЛАРІОНА ПАВЛЮКА БІЛИЙ ПОПІЛ}

\section{ОЛЕНА ВЕЩИКОВА}

Запорізький державний медичний університет, Запоріжжя - Україна veshchykova@gmail.com; ORCID: 0000-0003-2119-5495

\section{STRATEGIE NARRACYJNE W POWIEŚCI IŁŁARIONA PAWLUKA BIA Y POPIÓE}

\author{
OŁENA WESZCZYKOWA \\ Zaporoski Państwowy Uniwersytet Medyczny, Zaporoże - Ukraina
}

\begin{abstract}
STRESZCZENIE. Artykuł poświęcony jest analizie strategii narracyjnych w debiutanckiej powieści Iłłariona Pawluka Biały popiót. Celem artykułu jest ustalenie, jak zorganizowana jest narracja i jakie efekty artystyczne autor starał się osiągnąć, poprzez zwrócenie uwagi na intencje autora i śledzenie wpływu poszczególnych znaków tekstowych na odbiorcę. Analizowane są obecne w powieści cechy kryminału retro i noir jako gatunków „adrenaliny”. Zwrócono uwagę na kinematograficzny charakter pracy wynikający z pomysłu autora. Podkreślono wiodącą strategię narracyjną powieści - intertekstualność, w szczególności intertekstualne interakcje z opowieścią Mikołaja Gogola Wij oraz wpływ intertekstów na interpretację tekstu przez czytelnika. Rozpatrzono zjawisko nierzetelnej narracji na wybranym materiale i wykazano, że narrator homodiegetyczny - prywatny detektyw Taras Biłyj - jest niewiarygodny. Badana jest także strategia stosowania prolepsy i wywoływania wahania czytelnika, realizowana poprzez budzenie wątpliwości co do natury artystycznej umowności przedstawianych wydarzeń.
\end{abstract}

Słowa kluczowe: strategia narracyjna, kryminał retro, noir, intertekstualność, niewiarygodny narrator, prolepsis 


\title{
NARRATIVE STRATEGIES IN ILLARION PAVLIUK'S NOVEL WHITE ASH
}

\author{
OLENA VESHCHYKOVA \\ Zaporizhzhia State Medical University, Zaporizhzhia - Ukraine
}

\begin{abstract}
The article is devoted to the analysis of narrative strategies in the debut novel of Illarion Pavliuk White Ashes. Taking into consideration the author's intention and tracking the influence of the textual indicia on the recipient, the article aims to find out how the narration is organized and what artistic effects the author was trying to achieve. The features of retrodetective and noir as "adrenaline" genres present in the novel are analyzed. The cinematic qualities of the work as a result of the author's intention is marked. The leading narrative strategy used in the novel, the intertextuality, is highlighted, in particular, the intertextual interaction with the story of M. Hohol Vii, and the influence of intertextems on the reader's interpretation of the text. The phenomenon of unreliable narration is considered on the basis of the selected material and it is proved that the homodiegetic narrator, private detective Taras Bilyi, is unreliable. The strategy of using prolepsis and provoking the reader's hesitation which is realized through the formation of doubts about the nature of the artistic convention of the events described, is also examined.
\end{abstract}

Keywords: narrative strategy, retrodetective, noire, intertextuality, unreliable narrator, prolepsis

$\mathrm{H}$ аратив - це не сама історія, а спосіб розгортання історії, спосіб організації інформації, яку автор хоче презентувати читачеві; це вибір засобів, якими цю інформацію буде структуровано. Своєю чергою, наративна стратегія $є$ поняттям, що входить до категоріального апарату наратології як теорії оповіді, є складником організації тексту, втілення думок автора і персонажа через посередництво наратора. Наративна стратегія визначає письменницьку творчість через такі їі ознаки, як процедурність, усвідомленість, інтенційність, системність і селективність. Отже, під наративною стратегією розуміємо процес вибору й комбінування способів та прийомів організації оповіді, спрямований на досягнення певного художнього ефекту (авторська інтенція), а також базований на уявленнях автора про читача його творів і про особливості читацької рецепції тексту [Вещикова 2017: 29]. Мета цієї статті - простежити, як організовано оповідь і яких художніх ефектів намагався досягти Ілларіон Павлюк у романі Білий попіл. Цей прозовий твір є дебютним у творчості журналіста, продюсера і теледокументаліста Павлюка і наразі не був об’єктом спеціального літературознавчого дослідження, хоча й має значну кількість відгуків літературних критиків і читацьких рецензій.

В анотації до книги зазначено, що вона являє собою „трилер у стилі нуар” про приватного детектива [Павлюк 2020: 2]. Таку дифузію пригодницької 
прози (трилера, детективу, нуару, а також бойовика та містики, елементи яких наявні у творі) літературознавиця Тетяна Гребенюк означає як метажанр - „структурно-семіотичний інваріант побудови літературних творів, об'єднаних спільним предметом художнього зображення й однаковими закономірностями розвитку дії, яка розгортається за схемою, більш-менш жорстко регламентованою закономірностями літературної традиції” [Гребенюк 2010: 41]. Дослідниця масової літератури Софія Філоненко пропонує зарахувати бойовики, трилери, детективи і горори до так званих „адреналінових” жанрів, для яких характерний стрімкий темп розповіді, „сцени насильства, бійок, переслідування і втечі, вони викликають у читача гострі відчуття, «лоскочуть нерви»” [Філоненко 2011: 161]. Білий попіл, безперечно, $є$ таким „адреналіновим жанром". Уже в першому розділі читач спостерігає надзвичайно динамічну сцену бійки головного персонажа Тараса Білого з представниками київського криміналітету. У подальшому, маючи на меті досягти задуманого художнього ефекту, наратор постійно додає адреналіну і роман рясніє бійками, гонитвами, саспенсом, таємницями; кров тече ріками, автор щедро розкидує у фікційному світі трупи людей і тварин. Одним із цих трупів постійно ризикує стати головний герой, водночас сам тип оповідача - гомодієгетичний наратор в інтрадієгетичній ситуації (презентує власну історію від першої особи) - переконує реципієнта, що Тарас Білий не може загинути, інакше історія не була б оповіджена.

Ілларіон Павлюк спершу планував написати історію як сценарій фільму [Шестакова 2018], і тому цей задум реалізувався на наративному рівні як кінематографічний. Оксана Філатова, аналізуючи прийоми кіно в літературному тексті, наводить такі, як сконденсованість і лаконічність вираження фрази, фрагментарність, виразно окреслена подієвість [Філатова 2014: 192]. До таких кінематографічних прийомів зараховуємо також наявні у творі флешбеки (фрагментарні невиразні спогади про кохану дівчину), оповідь гомодієгетичного наратора, часто з використанням дієслів у теперішньому часі, що характеризується лаконічністю, відсутністю розлогих описів, пейзажів і ліричних відступів; читача ніщо не відриває від дії і почасти різких поворотів сюжету. 3 окремих кадрів, використовуючи прийом „частина замість цілого”, змінюючи плани, письменник за принципом „показувати, а не розповідати” будує монтажні фрази, що створюють враження яскравого цілісного емоційного образу, активізують зорове сприймання і уяву читача:

Тихо заходжу, двічі озираюся на сходи, - переконатися, що ніхто зненацька не вискочить 3-за спини. Відступаю від дверей і прислухаюся. Тиша, напівтемрява. Беззвучно беру двері на засув і прямую до секретера в передпокої. В одній із шухляд намацую заряджений пістоль. Хутко оглядаю єдину кімнату, їдальню та вбиральню: нікого. Опускаю зброю й навіть акуратно повертаю на місце зведений бойок, аж раптом нежданий звук за спиною 
змушує мене рвучко обернутися, скинувши пістоль і знову звівши курок. Але це лише вікно: мабуть, я забув його зачинити [Павлюк 2020: 30].

У романі Білий попіл можна виокремити і наративну стратегію, що надає жанрових ознак ретродетективу, оскільки сюжет побудовано на перенесенні історії в минуле - в середину 19 ст. Часові рамки чітко не окреслені, лише одного разу в тексті зазначено дату - вино 1852 року, яке п’є Тарас Білий, і читачеві відомо, що досі не скасовано кріпацтво (крім жителів самого хутора Білий Попіл, яких звільнили 1805 року). Отже, події мають відбуватися між 1852 і 1861 роками. Вбивство, яке розслідує приватний детектив, сталося за 20 років до самого розслідування, що досить прозоро натякає на дату першої публікації Вія Миколи Гоголя - 1835 р. Принаймні, згадувана в тексті київська вулиця Спаська вже існувала в 1855 році, а от Фундуклеївська отримала свою назву лише в 1869, тому в епізоді, де Тарас Білий „без поспіху, немов на прохідці, вийшов на Фундуклеївську й звернув у протилежний від готелю бік” [Павлюк 2020: 53], Ілларіон Павлюк дещо відходить від історичної правди. Власне, метою наративної стратегії було не стільки відтворити історичні реалії та дотримуватися хронології, скільки створити „симулякр минулого” (Жан Бодріяр), відповідну атмосферу, у яку цілком вписуються, наприклад, вигадані письменником шинок „Галіція” і готель „Жерар”; тобто це саме ретродетектив, а не історичний детектив (якому притаманні серйозна робота з історичним матеріалом і фактологічна точність). У цьому аспекті ми погоджуємося з тезою Юрія Ганошенка, що „історизоване тло не несе в собі заряду самостійної ідейності та естетичної вартості, [...] а перетворюється на театралізований, дещо екзотичний антураж, специфічну атмосферність [...], сама ж історія подіями романів містифікується й дещо карнавалізується" [Ганошенко 2015: 25]. Білий попіл не $є$ повноцінним „київським текстом” (яким $\epsilon$, наприклад, києвоцентричний роман Кохання у стилі бароко Володимира Даниленка), адже образ Києва окреслений лише побіжно, пунктиром; якби зав'язка історії відбулася, приміром, у Полтаві, художній ефект був би майже той самий.

Історичні художні деталі, стилізовані під 19 століття, надають наративу особливої екзотичності, допомагають реципієнтові зануритися в епоху, „поблукати” брудною Ямською вулицею „поміж борделів із перевіреною репутацією й украй сумнівними шинками та заїжджими дворами" [Павлюк 2020: 8], „походити” запиленими вуличками хутора Білий Попіл, „відвідати” сільську хату і панський маєток, „скласти компанію” нараторові в корчмі і шинку, „приміряти” шляхетну одежу і „костюм конюха”.

Тепер розглянемо прийоми оповіді, що формують наративну стратегію презентації роману як нуару. Нуар (від фр. noir - 'чорний') передбачає специфічний образ головного героя: у центрі оповіді - не детектив, а його ан- 
тагоніст - злодій, убивця, іноді - жертва; для нуару характерною є жорстка манера зображення, сленг, похмура атмосфера міста, напружений сюжет, що й реалізується в Білому попелі, повністю або частково. Жанр нуару висуває певні вимоги до образу головного героя: „Моральні оцінки, як правило, розмиті: жорстокість і несправедливість світу, тотальна корумпованість влади просто змушують героя вдаватися до насильства задля захисту самого себе чи близьких, часом задля помсти. Читача схиляють співчувати герою, не бездоганному в моральному сенсі; власне, позитивним героєм вважається той, хто вижив у фіналі” [Філоненко 2011: 225]. Як уже було зазначено, Тарас Білий у фіналі таки залишився живий, і читач співчуває йому, адже детектив, як і головні герої т. зв. „крутих детективів” (hardboiled), є розумним, сильним, спритним, хоробрим, іноді відчайдушним i нахабним, (само)іронічним аж до сарказму, з логічним і критичним мисленням, $є$ здатним на сильне кохання. Однак упродовж розвитку сюжету (особливо в розв'язці) розкривається і темний бік характеру протагоніста, коли жорстоку й цинічну поведінку формує та контролює підсвідомість слідчого. У класичному нуарі дія часто розгортається в кримінальних околицях, у барі, мотелі, підпільному гральному залі; зав'язка Білого попелу саме так змодельована - у будівлі в брудному маргінальному районі Києва, де грають в азартні ігри на великі гроші, а неможливість розрахуватися за програш означає вірну смерть. Для нуару також властивий специфічний хронотоп, заплутана хронологія подій, через що Тарас Білий з його спогадами 20-річної давнини справляє враження дезорієнтованого, а мешканці Білого Попелу, які влаштовують 40-денні поминки через два десятиліття після смерті Соломії, - щонайменше дивних.

Жанр нуару з'явився в американській літературі у 1920-х роках, проте справжнього розквіту досяг після екранізації у 1941 році роману Дешила Гемметта Мальтійський сокіл. Прикметно, що літературна критикиня Ганна Улюра вказує на очевидний інтертекстуальний зв'язок досліджуваного роману саме з Мальтійським соколом. На їі думку, обізнаність читача із класикою нуару впливатиме на його рецепцію Білого попелу як дослідження механізму тоталітарних сект [Улюра 2018]. Статуетка, що була предметом розшуку у Мальтійському соколі, - реліквія, що надає власникові здатність маніпулювати людьми, правити людством. А в досліджуваному романі роль очільника тоталітарної секти грає Анна - дружина сотника Назара Засухи, котра створила свій власний релігійний культ і забобонами тримає в покорі колишніх кріпаків, які так і не здобули справжньої свободи. Отже, інтертекстуальна наративна стратегія базується на співвідношенні досвіду наратора і досвіду реципієнта, і успішна реалізація цієї стратегії можлива, якщо читач $\epsilon$ „зразковим”, тобто спроможним упізнати претекст і адекватно інтерпретувати твір. 
Говорячи про інтертекстуальність, підходимо до провідної наративної стратегії в досліджуваному романі, яка значною мірою формує сюжет і почасти впливає на рецепцію роману як містичного. Ідеться про інтертекстуальний зв'язок із повістю Вій Миколи Гоголя, яку взято за основу фабули. Від Гоголя в Білому попелі - хутір під Києвом як локус розгортання подій, ім'я головного героя (Хома Брут), демон Вій, коло, окреслене крейдою, що має захищати від демона, мертва панночка, яка перед смертю називає свого вбивцю - Брута, і ії батько - сотник. А надалі Ілларіон Павлюк сміливо перетворює претекст до невпізнаваності, презентуючи читачеві такий собі постмодерний продукт - антифанфік (автор суттєво трансформує ідеї та конфлікти, закладені в оригіналі, міняє місцями позитивних і негативних персонажів) i пропонуючи альтернативне прочитання старого сюжету. Стосовно подібних експериментів із претекстом слушно висловився літературознавець Ярослав Поліщук: „У цьому випадку цікаві не так точки збігання, як не менш прикметні, зрештою, відступи від тексту-еталону або зумисні провокації щодо його смислових акцентів, які, поставлені в інший контекст (епохи, соціуму, психотипу), оновлюються, зазнають специфічного перекодування. Такі ефекти випадає означити як інверсивні, а їхня функція полягає в цілеспрямованому відсвіжуванні та верифікації образних конотацій, що були вже закріплені в літературній традиціі”' [Поліщук 2014: 276].

Моторошна містична повість Гоголя перетворюється в Білому попелі на (анти)детективний роман: порушено традиційну схему сюжету, підозрюваний у вбивстві відомий від початку, а слідчий має лише знайти його. Сотник Назар Засуха впродовж кількох місяців вистежує і наймає приватного детектива Тараса Білого, щоб він віднайшов убивцю його дочки Соломії - Хому Брута. Той три дні читав молитви над тілом померлої панночки, але не загинув від погляду Вія, як в оригіналі, а втік, хоча мешканці хутора і закликали демона спеціально до церкви, аби потойбічна істота покарала Брута. Дружина Засухи Анна будь-що намагається знищити вбивцю. Тарас Білий, оперуючи своїм критичним мисленням і почуттям справедливості, прагне не представити Засусі кривдника дочки для розправи, а довести чи спростувати його вину. За час розслідування у Білого виникає купа логічних запитань, які у своїй сукупності повністю руйнують надану йому версію вбивства. Ці запитання наратор-Білий, наближаючись до розв'язки сюжету і ніби нагадуючи читачеві суть перипетій, ставить Томашеві Болгару - загадковому персонажеві, який 3'являється невідь-звідки і так само таємничо зникає:

Якого біса сотник шукав Хому Брута щонайменше за місяць до вбивства? I чи було воно взагалі? Чому на поминках усім було байдужісінько до Соломії? Чому в маєтку немає iii кімнати? Як досі люди не повісили тебе, якщо більшість вважають за вбивцю? Нащо тобі здався я? Як у тебе опинився мій хрестик? Що ти знаєш про моє минуле? I взагалі - 
хто ти такий, бісова душа? Нащо морочив сотникові голову листами від імені Томаша Болгара? [Павлюк 2020: 273].

Відповідь на запитання „хто такий Томаш Болгар?” апелює до надзвичайно важливої наративної стратегії в романі Білий попіл - ненадійної (недостовірної) нарації. Нарація вважається ненадійною за умов явної невідповідності між змістом оповіді наратора і властивостями фікційного світу, якщо оповідач надає викривлені дані, пропонує неповне судження або лише частково правильну інтерпретацію подій. Критеріями ненадійності, які може відстежувати читач, постають індиціальні знаки автора (вказівка на дитячий вік персонажа-наратора, або на його одержимість певними ідеями, або на обмежену фокалізацію, або на явні суперечності між словами і вчинками, або сумніви самого оповідача у власній когнітивній компетентності). І передусім підозри в недостовірній оповіді виникають через сам тип наратора - гомодієгетичний. Як стверджує Вільям Рігган, першоособовий наратор завжди потенційно ненадійний через „обмеженість людського сприйняття, пам'ять і судження, котрі можуть пропустити, забути, неправильно витлумачити певні події, слова чи мотиви" [Riggan 1981: 19-20] (переклад автор. - О.В.).

У романі наявні текстові сигнали, що створюють ефект ненадійності через неповну когнітивну компетентність наратора: Тарас Білий після травми 20-річної давнини втратив пам'ять і не може згадати події, які передували цьому, лише має уривки спогадів: на його руках кохана дівчина, вона вмирає, він тримає закривавлений камінь. Врешті виявляється, що загадковий Томаш Болгар - це друге „я” самого Тараса Білого, допельгангер, що втілює витіснені, несумісні з моральними цінностями бажання, темний бік підсвідомості, який активізувався після бійки і травми в кримінальному притоні і визначав його негативні вчинки і насильницькі нахили. Більше того, згодом Тарас Білий пригадав, що він і Хома Брут - одна особа. На думку Т. Гребенюк, у процесі читання ненадійного розповідного тексту реципієнт отримує задоволення не тільки від розв' язки, але й від усвідомлення того, як і чому реальний хід подій був спотворений у свідомості наратора [Grebeniuk 2020: 47]. Тому розв'язка (до вбивства Соломії причетний не Тарас-Хома, а Анна Засуха, яка навіть не була ій рідною матір'ю) виявляється досить несподіваною і вражає читача.

Загадки й натяки щодо обставин убивства Соломії Засухи й особистості Тараса Білого, розкидані по тексту, діють на читача як наживки, що стимулюють читацький інтерес. Пролепсис $є$ одним із найефективніших художніх засобів, здатних сформувати уявлення читача про подальший перебіг подій твору і водночас тримати його в невизначеності, змушувати відстежувати реалізацію передбачення. У теорії наративу цей термін з'явився завдяки Жерару Женетту, який розробляв аспект темпоральності художнього твору у праці Наративний дискурс. Натяками (за Ж. Женетттом, пролепсисами-анонсами) 
на структуру особистості Тараса Білого є ідентичність латинських ініціалів (T.B. - Tomas Brutus, Tomasz Bolgar); тлумачення імені Хома - 'близнюк'; однакова унікальна навичка Брута і Болгара однією рукою скручувати самокрутку; старе пальто із заячим коміром, у яке був одягнений Болгар і яке виявилося у скрині в старій хаті Хоми Брута. Як пролепсис виступають і сновидіння приватного детектива, погані передчуття (,... в вікнах було іще темно. «Наче в очах мертв'яка», - привіялось порівняння, і я подумки сплюнув через ліве плече, щоб відігнати похмуре передчуття" [Павлюк 2020: 10]), передбачення про майбутнє від Томаша Болгара (,А запропонує він, Тарасе, найбільшу оборудку в твоєму житті. Й ти - погодишся” [Павлюк 2020: 38]), сама чергова поява Болгара - до біди [Павлюк 2020: 206].

Стратегія провокування читацького вагання реалізується через формування сумніву щодо характеру художньої умовності зображуваних подій: реципієнт вагається між містичною і немістичною інтерпретацією наратованого. 3 одного боку, сюжетна лінія демона Вія - цілком містична, з іншого - Тарас Білий постійно знаходить логічне пояснення дивним заплутаним подіям: незвично білий пил, що встеляє все в хуторі - це не попіл із брами пекла поблизу, а крейдяні відклади на поверхні землі; „жива вода”, яка рятує від „білої немочі” - холери - проста кип’ячена, чарівні ліки - сода й вугілля, „мертва вода” - дезінфектор для рук із вмістом оцту; величезний сивий вовк - не аватар Вія, а скажена тварина, що вивалялася у крейді. І розв'язка роману $є$ немістичною, містичний настрій деяких епізодів навіюється скоріше читачеві, ніж характерний для персонажів.

Отже, Білий попіл Ілларіона Павлюка - містичний ретродетектив з елементами нуару про приватного детектива Тараса Білого, який розслідує вбивство панночки, а підозрюваний - Хома Брут. Звертаючи увагу на авторську інтенцію та відстежуючи вплив на реципієнта індиціальних знаків, наявних у тексті, ми з'ясували, що одна з провідних наративних стратегій, задіяних у романі, - інтертекстуальна взаємодія з повістю М. Гоголя Вій, маніпулювання читацькою рецепцією, навіювання містичного настрою завдяки конкретним текстовим сигналам. Також виявлено стратегії ненадійної нарації, провокування читацького вагання у сприйманні наратованого містичного досвіду персонажа, використання пролептичних засобів тощо.

\section{Список використаної літератури}

Вещикова О.С., Наративні стратегії містичного у художньому творі (на матеріалі прози В. Шевчука, Г. Пагутяк, В. Даниленка), дис. ... канд. філол. наук, Запоріжжя 2017. 
Ганошенко Ю.А., Археологія психічного: онтологія часу в сучасній українській прозі, [в:] „Наукові праці Чорноморського державного університету імені Петра Могили. Серія: Філологія. Літературознавство”, 2015, т. 259, вип. 247, с. 24-28.

Гребенюк Т.В., Подія в художній системі сучасної української прози: морфологія, семіотика, рецепиія, Запоріжжя: Просвіта, 2010.

Поліщук Я., Інверсія смислів у текстовому діалозі (М. Коцюбинський-М. Хвильовий), [w:] „Studia Ukrainica Posnaniensia”, 2014, nr 2, s. 271-282.

Улюра Г., Дама б’є валета, король б'є даму, [в:] Електронний ресурс: https://lb.ua/ culture/2018/08/10/404808_dama_bie_valeta_korol_bie_damu_html (14.11.2020).

Філатова О., Жанрові гібриди, або прийоми кіно в літературному тексті, [w:] „Studia Ukrainica Posnaniensia", 2014, nr 2, s. 187-193.

Філоненко С.О., Масова література в Украӥні: дискурс/гендер/жанр, Донецьк: ЛАНДОН-ХХІ, 2011.

Шестакова Ю., Ілларіон Павлюк про свою книжку: „, Свідомо хотів експлуатувати саме Гоголя, бо росіяни, здається, його вже приватизували”, [в:] Електронний ресурс: https://detector.media/community/article/136306/2018-04-03-illarion-pavlyuk-pro-svoyuknizhku-svidomo-khotiv-ekspluatuvati-same-gogolya-bo-rosiyani-zdaetsya-iogo-vzheprivatizuvali/ (14.11.2020).

Grebeniuk T., Narrative Unreliability in Paula Hawkins' The Girl on the Train as a Strategy of Reader Immersion, [in:] “American \& British Studies Annual”, 2018, vol. 11, p. 36-48. Riggan W., Picaros, Madmen, Naifs, and Clowns: The Unreliable First-Person narrator, Norman: U of Oklahoma P., 1981.

\section{Spysok vykorystanoi literatury [References]}

Veshchykova O.S., Naratyvni stratehii mistychnoho u khudozhnomu tvori (na materiali prozy V. Shevchuka, H. Pahutiak, V. Danylenka) [The Narrative Strategies of the Mystical in Fiction (on the Prose by V. Shevchuk, H. Pahutiak, V. Danylenko)], dys. ... kand. filol. nauk, Zaporizhzhia 2017.

Hanoshenko Yu. A., Arkheolohiia psykhichnoho: ontolohiia chasu v suchasnii ukrainskii prozi [Archeology of The Mental: The Ontology of Time In Modern Ukrainian Prose], [v:] „Naukovi pratsi Chornomorskoho derzhavnoho universytetu imeni Petra Mohyly. Seriia: Filolohiia. Literaturoznavstvo", 2015, t. 259, vyp. 247, s. 24-28.

Hrebeniuk T.V., Podiia v khudozhnii systemi suchasnoi ukrainskoi prozy: morfolohiia, semiotyka, retseptsiia [Event In The Artistic System Of Modern Ukrainian Prose: Morphology, Semiotics, Reception], Zaporizhzhia: Prosvita, 2010.

Polishchuk Ya., Inversiia smysliv u tekstovomu dialozi (M. Kotsiubynskyi - M. Khvylovyi) [The Inversion of Meanings in The Dialog Of Texts (by Novels of M. Kotsubynskiy And M. Khvyloviy)], [w:] „Studia Ukrainica Posnaniensia”, 2014, nr 2, s. 271-282. 
Uliura H., Dama bie valeta, korol bie damu [The Queen Beats The Jack, The King Beats The Queen], [v:] Elektronnyi resurs: https://lb.ua/culture/2018/08/10/404808_dama_bie_valeta_ korol_bie_damu_html (14.11.2020).

Filatova O., Zhanrovi hibrydy, abo pryiomy kino v literaturnomu teksti [Genre Hybrids or Cinematic Techniques in A Literary Text], [w:] „Studia Ukrainica Posnaniensia”, 2014, nr 2, s. 187-193.

Filonenko S.O., Masova literatura v Ukraini: dyskurs/gender/zhanr [Mass Literature In Ukraine: Discourse/Gender/Genre], Donetsk: LANDON-XXI, 2011.

Shestakova Yu., Illarion Pavliuk pro svoiu knyzhku: ,Svidomo khotiv ekspluatuvaty same Hoholia, bo rosiiany, zdaietsia, yoho vzhe pryvatyzuvaly" [Illarion Pavliuk about his book: "I consciously wanted to exploit Hohol, because the russians, it seems, have already privatized him "], [v:] Elektronnyi resurs: https://detector.media/community/article/136306/2018-0403-illarion-pavlyuk-pro-svoyu-knizhku-svidomo-khotiv-ekspluatuvati-same-gogolya-borosiyani-zdaetsya-iogo-vzhe-privatizuvali/ (14.11.2020).

Grebeniuk T., Narrative Unreliability in Paula Hawkins' The Girl on the Train as a Strategy of Reader Immersion, [in:] “American \& British Studies Annual”, 2018, vol. 11, p. 36-48.

Riggan W., Picaros, Madmen, Naifs, and Clowns: The Unreliable First-Person narrator, Norman: U of Oklahoma P., 1981.

\section{Використане джерело}

Павлюк І., Білий попіл, пер. М. Бриних, Львів: Видавництво Старого Лева, 2020.

\section{Vykorystane dzherelo [References]}

Pavliuk I., Bilyi popil [White Ash], per. M. Brynykh, Lviv: Vydavnytstvo Staroho Leva, 2020. 